\title{
Currency Union and East Asia
}

\author{
Ma. Kresna D. Navarro, MA
}

mnavarro@xu.edu.ph

\section{Doi:10.5901/mjss.2015.v6n2p415}

\begin{abstract}
This paper examines the feasibility of the proposal to establish a currency union in the East Asia. In this paper East Asia is composed of ASEAN countries like Brunei Darussalam, Cambodia, Indonesia, Lao PDR, Malaysia, Myanmar, Philippines, Singapore, Thailand and Viet Nam, plus three countries - Japan, China and South Korea. The test for feasibility, the study used Mundell's concept of factor mobility, Kenen's trade openness and McKinnon's product diversification. Results indicate that within East Asian countries, intra labor mobility is immobile. Labor would rather move to European Union 6 countries and United States than stay within the region. Intra capital mobility, on the other hand, is slightly mobile. The average East Asian share of foreign direct investment to gross fixed capital formation is relatively higher compared to developed counties like United States, Germany and France. In terms of trade openness, the volume of trade is relatively higher within the region than the volume of trade in European Union 6 countries and United States. However, it is less symmetric. This means, some countries exports within the region but imports outside the region. Furthermore, there has been increasing diversification of trade within the region. There is even a rise of the share of parts and components in manufacturing. Hence, base on the given results, East Asia is not yet ready to form a currency union.
\end{abstract}

Keywords: Currency Union, East Asia, Optimum Currency Area, Factor Mobility

\section{Introduction}

Currency Union defines as "either small client countries adopt the currency of a large anchor country or a group of countries creates a new currency and a new joint central bank" (Alesina et al, 2002). The motivation of creating or joining a currency union evolved on the objective of minimizing transaction cost incurred from currency conversion and opportunity cost due to speculative bubbles, insulation from monetary disturbances, and protection from the absence of credible domestic public institution.

The benefits of the currency union to its members have been known for several decades. Hence, many currency unions emerged as early as $4^{\text {th }}$ century but European Monetary Union (EMU) is commonly used model of currency union in this contemporary time. The European Monetary Union illustrates the bitter sweet success and challenges of a currency union bring to country members. The crisis in the European Monetary Union has post questions on the viability of the currency union. The literature, on the matter at hand, suggests that the Union is not an Optimum Currency Area, which is the reason for the rippling problem in the Union. Articles on currency union explain that benefits from currency union can be maximized as group achieves the bases of currency union, or criteria for Optimum Currency Area (OCA).

While Europe is struggling to the consequences on their Union, East Asia region has something to say about the issue. In the wake of the US financial crisis in 2007, East Asian leaders observed the vulnerability of the each country's exchange rate to US dollar. Economists in the region suggest that a single currency within the region might reduce the effect of the financial crisis. This was proposed by former Japan's Prime Minister Yukio Hatoyama in August 2009, which prompted interests to countries like Republic of Korea and China. Then, it obtained support from Korean professor Kim In-June. East Asian (ASEAN plus three) will have a monetary union with single currency but with an exchange rate arrangement that is based on the currencies of the East Asian countries.

\subsection{Objective of the Study}

This paper attempts to assess the possibility of the proposal to establish a currency union in East Asia. Likewise, it will elucidate possibility of the proposal to create currency union in East Asian community. Monetary union is a much awaited breakthrough for a region of diversified culture and history but with one goal: financial stability through a single currency. More so, it attempts to present the benefits and cost of a possibility for currency union in East Asian region. 


\section{Review of Related Literature}

\subsection{Bases of Optimum Currency Area}

Currency union defines as "either small client countries adopt the currency of a large anchor country or a group of countries creates a new currency and a new joint central bank" (Alesina et al, 2002). It is also characterized as using a fixed exchange rate between trading partners or within trading area which stabilizes prices, fostering economic integration and trade liberalization.

The decision of creating a currency union takes more than a formal gathering between trading partners. It also entails political change within the organization. As early as 1960's, enthusiast on currency unions laid down several bases for its formation. Mundell's Optimum Currency Area (OCA) became the pillar for the formation of currency union. Within a span of 8 years, McKinnon (1963) and Kenen (1969) posited additional Optimum Currency Area criteria.

Factor Mobility and Optimum Currency Area. The concept of factor mobility has been the primary source of gains from trade. In the Hecksher-Ohlin model, factor mobility is one of the assumptions for gains from trade to be maximized. This paramount input for trade is also the core of Mundell's seminal paper, a basis for currency union. At the same time, mobility of these factors: labor and capital, serves as adjustment mechanism for periodic balance of payment crisis (together with price and wage flexibility). Hence, not only that factor mobility is a catalyst for currency unification but also a medium to effectively promote balance of payment equilibrium. Balance of payment issues is part of the package once a country engaged into international trading.

Factor mobility defines a region. Mundell pointed out that factor must be mobile internally but not externally. His argument was illustrated through an example. Suppose there are two regions East and West. The East produces cars while the West produces lumber. A shift in the demand for cars to lumber would cause unemployment in the East and an inflationary pressure in the West. A flexible exchange rate will correct the imbalance of payment between countries but not between two regions. The restoration of the balance of payment equilibrium between regions will be amended through factor mobility. High degree of factor mobility demarcates optimum currency area. He defined currency area as "domain within which exchange rates are fixed" (Mundell, 1961). This can also be characterized with a single currency within the area. This property forms countless possibilities on the efficient functions of money as a unit of account, store of value and the principal role as a medium of exchange. Money becomes less useful when having multiple currencies. As so, market transaction goes back to medieval barter system.

Sahin (2006) mentioned factor mobility as a tool for adjustment mechanism following exchange rate crisis and macroeconomic shock. Suppose recession hits Home country following continuous decline in production, with high degree of factor mobility between countries, laborers from Home country can move from one country to another. This ease unemployment crisis in Home country and allows recovery from the shock.

The earlier paper of Mundell suggests heavily on the importance of labor mobility. He even suggested that sufficient labor flexibility can help reduce asymmetric shocks within the union. It was only in his 1963 paper that he stressed that capital mobility is equivalently important tool for adjustment mechanism to counteract negative effects of asymmetric shocks.

McKinnon and Kenen. Within a span of 8 years, McKinnon (1963) and Kenen (1969) posited additional OCA criteria. The latter stressed that immobility of factor inputs is possible due to the fact that some inputs are for specialized production and due to some geographical consideration. He suggested that the degree of openness determines the size of the currency union. Kenen, on the other hand, insisted that labor mobility rarely exists unless labor is homogenous within trading area. The homogeneity of the labor means similar skills and knowledge of product creation, which as worker invests, its productivity changes. In this case, homogenous labor is impossible. Instead, Kenen added product diversification on the criteria for currency union. Each assertion will be discussed in the succeeding paragraphs.

Trade Openness. Optimum was described by McKinnon (1963, pp. 717) as "a single currency area within which monetary-fiscal policy and flexible external exchange rates can be used to give the best solution of the three conflicting objective". These three objectives are full employment, balance of trade and price stability. He focused on how openness of the country affects the internal price stability. He then continued his assertion by classifying goods, either tradable or non-tradable in terms of its feasibility to be transported. Hence, openness of a country was determined by the ratio of the tradable goods to non tradable goods. As country becomes highly open by having more tradable goods than non tradable goods, flexible exchange rates become less effective in maintaining balance of trade and price stability. He suggested that "for an open economy, a policy of completely fixed exchange rates (or common currency ties with the outside world) would be optimal" (pp. 719).

The creation of European Economic Community (ECC) in 1957 motivates members to intensify intra regional 
trading by adhering to a single currency with a fixed exchange rate. This interest common to all members sparks series of events that lead to formation of European Union. Malhotra \& Mariotz (2005) examined the pre and post periods of the Maastricht Treaty in European Union to assess improvement in the region as a result of the integration. The effectiveness of the regional trading was measured in terms of economic and non-economic factor. They found out that during the post treaty, economic improvement was evident in the region but uneven among all nations in the European Union. On the downside, most citizens had sentiments on how politicians run their government. In a study of Auray et al (2009), he found out that horizontal and vertical trade integration reduced inflation differential as a result of increased trade flows. As a result, the common monetary policy of the Union speaks for the national situations. There is congruency of the monetary policy of the Union and the monetary issues within each country.

Bergman \& Jonung (2010) studied the business cycle synchronization in the three countries that formed the Scandinavian Currency Union. Results showed that Scandinavian countries were more synchronized during the period of the Scandinavian Currency Union compared to the post World War II but not before the formation of the Union. They suggested that increased economic integration resulted to more synchronized business cycle. Positive relationship of economic integration and synchronization of business cycle was also detected in the study of De Pace (2011). He studied the business cycle synchronization of free trade area like North American Free Trade Agreement (NAFTA). He observed that there was an increase in pairwise movement in output and consumption between Mexico and the US, and between Mexico and Canada in consumption, gross fixed capital formation and stock market return.

Product diversification. Kenen (1969) insisted that labor mobility rarely exists unless labor is homogenous within trading area. The homogeneity of the labor means similar skills and knowledge of product creation, which as worker invests on his human capital, its productivity changes. In this case, homogenous labor is impossible. Instead, he asserted on product diversification. He suggested "...diversity in a nation's product mix, the number of single-product regions contained in a single country, may be more relevant than labour mobility" (Kenen, 1969). A country with diversified products can easily handle demand shocks than country with specialized product. To further explicate his point, a diversified economy also means a diversified export sector. Any macroeconomic disturbances will partially affect a diverse economy. Thus, an economy with diversified products can tolerate small costs of their abandoning monetary independence, and will benefit from single currency.

Costa Neto and Romeu (2011) investigated the impact of greater trade diversification to the export performance of Latin American countries during the financial crisis of 2008-2009. The study used a trade dataset disaggregated at the four digit level of the Harmonized System of classifying trade. Results indicated that product diversification lessen trade collapse. However, a different result was made from the paper of Baldwin, Caves and Gu (2005) as they examined the Canadian experience following the adoption of the Canada-United States Free Trade Agreement in the early 1990s. They observed that there was an increase in the commodity specialization between Canada and United States from the time they implemented the Free Trade Agreement. They further explained that plant diversity was higher in industries with higher rates of tariff protection. This explains the declining product diversification for countries within free trade agreement.

On the other hand, Tenreyro, Caselli, Koren \& Lisicky (2010) argued on the established view that trade induces specialization. Instead, they also claim that country wide shocks were as important as sector specific shocks in shaping volatility patterns. They also added that trade was even a source of diversification. When country wide shock is dominant than sector specific shock, trade and output volatility has negative relationship. This can be observed when a domestic producer experience country wide shock, they shift sourcing outside, resulting to diversified production.

\subsection{Gains and Losses from Currency Union}

The formidable decline in the number of currencies in circulation and the rise of currency unions, either adopting a stable currency or creating a new currency which is applicable within their union, is a breakthrough for better trading environment. However, the benefits from currency union might be unevenly distributed to the members, some may benefit more than the others, while some countries may even experience welfare deterioration following the entry to the union. Hence, this section will discuss tradeoffs face by economies from surrendering their own monetary policy for a unified central bank or adoption of another currency. Three major points will be presented in this section.

Economic Effect. Theme on currency union centered on the economic benefits from joining currency union, and little was mentioned on other issues surrounding monetary union like welfare and stabilization effect. This section will intensely examine the latter, and a section will be given for the discussion of the former. This section centers on trade effect, co-movement of wages and output, risk sharing, transaction cost and investment environment following the entry to currency union. 
The long standing effect of currency union to trade is framed within a "gravity model". Rose (2000) used a panel data set of bilateral observation for five spans of years 1970 through 1990 for 186 countries. With 100 pairings and 300 hundred observations, in which both countries used the same currency, results indicated that two countries sharing the same currency trade three times as much as they would if they were using single currency. On another study, Rose and Glick (2001) used large annual data for 217 countries from 1948 to 1997. They found out that those countries left currency union experienced statistically significant decline in their trade performance.

However, maximizing the trade effects of the currency union is dependent on the similarities of the economy across member countries. In the study Albertin (2008), she investigated the role of economic dissimilarities across countries on the extent of the trade effects from the formation of currency union. He also examined the trade pattern between non-union and union member. The creation of currency union affects the pattern of trade by reducing the trade cost occurred in the swapping of different currencies, "and by a general equilibrium induced reduction of the relative wage in the non-member countries" (Albertin, pp 17). This induces the volume of bilateral trading with member countries and reduces the volume of bilateral trading between member and non member countries. Economically dissimilar country joining a currency union has the same trade effects of bilateral trading between member and non member countries. A country that is economically different from the rest of the member countries will experience deterioration in the volume of their bilateral trading.

Aside from trade impact from currency union, entry to currency union significantly increase the extent of wage comovement. Kurokawa, Pang \& Tang (2011) examined the relationship of the different exchange rate regime to nominal wage co-movement between trading countries. They used data from 24 Organisation for Economic Co-operation and Development (OECD) countries between 1973 and 2010. Results revealed that was a statistically significant positive comovement of wages for those European Union countries engaging intra trading while a statistically weaker positive wage co-movement for country pairs who are non-currency union pegs. They also concluded that those European Union countries that joined the European Monetary Union (EMU) in 1999 had significant increase in wage co-movement compared to periods prior to 1999.

Lee and Shin (2006) investigated the effect of the three exchange rate regime: currency union, peg and floating exchange rate, to economic linkages like bilateral trade, output co-movement and risk sharing between countries. The authors suggested that in terms of statistical increase in bilateral trade, currency union affects the most followed by currency pegged to anchor country. Currency union can enhance consumption co-movement than peg regime. However, currency union does not lead to output co-movement, unlike peg regime that it can improve output co-movement. On the other hand, as explained by the author, risk sharing can be enhanced once consumption co-movement dominates output co-movement. Hence, in this case currency union can improve risk sharing than a peg regime.

Welfare Effect. Adhering to the joint monetary policy does not only permit country to take advantage of the economic benefits that currency union can bring but also an increase the welfare effect. This section discusses transportation cost, co-movement of prices and output, inflation effect and seigniorage wealth.

Bayoumi (1994) discusses the welfare gains and losses for joining currency union. Result of his model indicated that welfare gain was a result of lower transaction costs associated with trade with the other members of the union. The degree to which domestic consumers' desire on foreign goods and the expected costs of joining the union depends upon the importance of the consumption of all the goods produced in the currency union and the correlation of the disturbances across countries in the union. In most cases, country with dissimilar disturbances with other countries in the union may have loss more than gains from joining currency union. He concluded that the welfare effects of a reduced transaction cost will be experienced by countries within the currency union but the losses like lower output as a result of "interaction between the common exchange rate and the nominal rigidity" (Bayoumi, pp. 14) will be experienced even to non union members.

Isgut (2002) extended the work by Parsley and Wei (2001) on determinants of price dispersion across city pairs in 2001. He examined the link between the use of shared currency and the extent of integration in consumer goods and services markets across cities. He added that euro statistically significant in affecting the reduction of price dispersion across cities. Despite controlling trade integration and other features shared by cities located in the same country. Cities that are located in the countries that use dollar pegged currencies have still reduction effect on price dispersion but it was not statistically significant.

Reforms and Monetary Stability. Monetary union has sets of policies that work for the member. These policies are made to synchronize shocks and to address shocks the soonest it hit the union. In this section it will discuss the advantage and disadvantages of the unified reforms and stabilization policies to the union members.

Monetary policy along with fiscal policy serves as an automatic stabilizer in the economy. Losing monetary independence is one of the tradeoffs a country faced once it joins the currency union. Following an entry to currency 
union, it has to adhere to the joint monetary policy. De Grauwe (2011) pointed out the governance issue inside monetary union. Union members tend to haphazardly spend or issue debts since the joint central bank can provide the liquidity to the country to avoid default or insolvency. This creates rippling effect to other union member. This problem intensifies as there was no provision on how to deal with defaults. At the same time, the Maastricht Treaty has no exit procedure. Cooper (2012) studied various forms of exit in the European Monetary Union. He proposed two procedures for exit to punish countries in default: bailout and Euroization, which as "using the common currency of the monetary union but is not involved in policy determination" (Cooper, pp 8).

Arguments on fiscal coordination failure likely will occur in currency union. Beetsma et al. (2001) examined the possibility of fiscal policy as a demand management tool in currency union. Results from their model showed that fiscal coordination policy is desirable once the union is hit by asymmetric shocks. The presence of the fiscal coordination can be counterproductive to the monetary policy set by the joint central bank.

\section{Theoretical Framework}

The criteria of optimum currency union started from Mundell's seminal paper, suggested high degree of factor mobility demarcates optimum currency area. McKinnon added trade openness and Kennen's product diversification as the focal criteria for optimum currency union. But it was only in the paper of Alesina \& Barro (2002) on which a formal model for currency union was established. This paper will use the model developed by Alesina \& Barro.

\subsection{Empirical Implication}

The model shows how trading cost, $b$ affects the level of domestic consumption and production, hence, the volume of trade. Higher trading cost reduces the volume of trade. The parameter ${ }^{b}$ relates to the distance of the trading partners. It measures transportation costs, costs due to conversion of currencies, legal system, language, culture, government policies, business practices and other variables related to trading beyond country border. In the literature, sharing a common currency lessens trading costs which leads to high volume of trade. Suppose joining a currency union entails a cost. Does a country with high volume of trade willing to incur another cost for adopting to a common currency?

This incentive of joining a currency union revolves around the impact of currency union to trading. Trade is affected by trading cost and elasticity of substitution. Countries with lower trading costs will most likely create a currency union, since lower trading cost increases trade volume. As pointed out by Tenreyro (2001), the proportional gains on trade from sharing a common currency:

$$
\frac{\partial \text { VTrade }}{\partial b} \sim(1-b)^{\frac{2 \alpha-1}{1-\alpha}}
$$

If ${ }^{\alpha>\frac{1}{2}}$, then the intermediate goods are relatively close substitutes, lowering $b$ will saves on the trading costs incurred. If ${ }^{\alpha<\frac{1}{2}}$, then intermediates are poor substitutes, lowering $b$ will have high impact on trading. Hence, countries that share common currency have been trading with relatively close substitute tradable goods.

\subsection{Methodology and Data Source}

There are no annual intra ASEAN data, more so, an intra East Asian labor flows data available for all countries. Instead, the study utilized the Global Migration Database from the World Bank for five-decade period. Labor migration is the nearest illustration for labor mobility. To show the labor mobility within East Asia, cross tabulation were employed. Also, it presented a comparative outbound and inbound migration ratio between intra-East Asia, European Union 6 countries and United States. European Union 6 countries include Belgium, France Germany, Italy, Luxembourg and the Netherlands. These are the countries that initial signed for single currency in Europe.

Capital mobility for each country is reflected by the share of foreign direct investment (FDI) to gross domestic product (GDP). Data of the country's flows of foreign investment were obtained from United Nations Conference on Trade and Development (UNCTAD). Moreover, it showed the share of FDI inflows to gross fixed capital formation from year 1990 to 2010. To compare the trend of the flow of investment, periods were separated as before the Asian crisis in 1997, 1997 to 1998, 1999 until before US crunch in 2007, and 2007 to 2010. Data on intra regional investment was obtained from ASEAN database. Hence, cross tabulation were employed from the source of the foreign investment to the host of the investment. 
Data on trade were obtained from United Nations Conference on Trade and Development (UNCTAD) and was cross tabulated according to trade groupings: ASEAN, ASEAN + 3, EU 25 and United States. There were five (5) periods with a span five years; 1992, 1997, 2002 and 2007. It also utilized data from the World Bank's World Trade Integration Solution to show the one on one relationship of each ASEAN member and its trading partners.

Components of the products traded are shown to reflect the extent of product diversification in the country. Data on the components of traded commodities per East Asian countries (ASEAN plus China, The Republic of Korea and Japan) were obtained from UN Comtrade database which was used in the study of Athukorala (2011). For this section, all the data comes from the said paper, like the table that shows the composition of manufacturing exports, 2006-07 and share of parts and components in manufacturing trade, 1992-03 and 2006-07.

\section{Results and Discussions}

This section discusses the feasibility of the proposal to form a single currency in the East Asia community. The presentation of the benefits and costs of the currency union depends on the result of study. Tables are also shown to expound the results. In this study, the bases for currency union are factor mobility, trade intensity and product diversification.

\subsection{Labor Mobility}

During the oil price boom and the expansion of Middle East in 1970s, many Asian laborers were attracted to discover the other side of Asia. Influx of workers from different Asian region moved into successful Gulf countries like Saudi Arabia, United Arab Emirates specifically Dubai Emirate and Kuwait. Then, in 1980s, many East Asian starts migrating to their neighboring countries. Singapore was then the country destination in Southeast Asia for job hunters. Presently, there are other options for job seekers countries like Thailand, Malaysia and Japan have attractive labor bilateral agreement.

Table 1. Ratio of Outbound and Inbound Intra-East Asia Migration

\begin{tabular}{|c|c|c|c|c|c|c|}
\hline East Asia & 1960 & 1970 & 1980 & 1990 & $\mathbf{2 0 0 0}$ & $\mathbf{2 0 1 0}$ \\
\hline Brunei Darussalam & 0 & 0 & 0 & 0.1 & 0.1 & 7.2 \\
Cambodia & 0 & 0 & 3.3 & 0.4 & 0.2 & 17.2 \\
China & 15.9 & 37.4 & 55.6 & 34.1 & 12 & - \\
Indonesia & 0 & 0.1 & 0.2 & 1 & 9.9 & 2076.5 \\
Japan & 0 & 0.1 & 0 & 0 & 0 & 4.3 \\
Korea, Rep. & 28.7 & 25.8 & 38.4 & 73.6 & 7.6 & - \\
Lao PDR & 0.7 & 0.9 & 1 & 1 & 2.7 & 687.1 \\
Malaysia & 3.6 & 0.4 & 0.5 & 0.5 & 0.6 & 57.0 \\
Myanmar & 0.2 & 0.1 & 0.4 & 0.8 & 3.7 & 774.3 \\
Philippines & 0.1 & 0.2 & 0.9 & 2.5 & 2.1 & 845.3 \\
Singapore & 0 & 0.1 & 0.1 & 0.1 & 0.1 & 6.7 \\
Thailand & 0.4 & 0.5 & 0.2 & 0.4 & 0.4 & 35.1 \\
Vietnam & 76 & 67.3 & 16.7 & 9.3 & 6.5 & - \\
\hline
\end{tabular}

Note: (-) means no data at the time of the study.

^Source: Author's computation based on migration data from http://go.worldbank.org/JITC7NYTTO. Accessed 31 July, 2012.

As presented in the table, intra-East Asia migration has increased considerably within the span of 50 years. Figures less than 1.0 ratio of outbound and inbound labor movement denotes lesser incidence of inbound labor movement than outbound, higher than 1.0 ratio means more incidence of outbound labor movement than inbound; and therefore 1.0 ratio reflects the same inbound and outbound movement of labor. Notice an increasing incidence of labor movement from their respective country to other countries. Although for considerable period countries like Brunei D., Japan, Malaysia, Singapore and Thailand have more laborers joining their domestic labor force than their own labor force joining other labor force abroad.

Table 2 reveals the share of intra-East Asia to total migration shows asymmetry of labor movement. In year 2010, Thailand has the highest incidence of outbound labor movement. As shown in the table, out of more than eight hundred people move out in Thailand only 37 percent stayed within the region. Whereas, in the Myanmar 61 percent of the outbound labor stayed in East Asia. This is also observed in the earlier period, for example, Japan has more than two million inbound laborers of which less than one percent comes from East Asia, while for Malaysia 86 percent of the laborers are from East Asia. 
Table 2. Share of Intra-East Asia to Total Migration for Year 2005 \& 2010

\begin{tabular}{|c|c|c|c|c|c|c|c|c|}
\hline \multirow{3}{*}{ East Asia } & \multicolumn{3}{|c|}{$\mathbf{2 0 0 5}$} & \multicolumn{4}{c|}{$\mathbf{2 0 1 0}$} \\
\cline { 2 - 8 } & \multicolumn{2}{|c|}{ Total Migration } & \multicolumn{2}{c|}{$\begin{array}{c}\text { Share of Intra-East Asia to } \\
\text { Total Migration (\%) }\end{array}$} & \multicolumn{2}{c|}{$\begin{array}{c}\text { Total Migration } \\
\mathbf{2 0 1 0}\end{array}$} & \multicolumn{2}{c|}{$\begin{array}{c}\text { Share of Intra-East Asia to } \\
\text { Total Migration (\%) }\end{array}$} \\
\cline { 2 - 8 } & Outbound & Inbound & Outbound & Inbound & Outbound & Inbound & Outbound & Inbound \\
\hline Brunei Darussalam & 12622.68 & 124193 & 6.83 & 83.77 & 24343.04 & 148123 & 36.72 & 83.77 \\
Cambodia & 348710.2 & 303871 & 0.50 & 97.87 & 350485 & 335829 & 16.11 & 97.87 \\
China & 7258333 & 595657.9 & 5.34 & 0.00 & 8344726 & 685775 & 24.30 & 0.00 \\
Indonesia & 1736717 & 159731 & 41.07 & 64.20 & 2504297 & 397124 & 63.77 & 19.37 \\
Japan & 940027.8 & 2048487 & 0.87 & 0.08 & 771245.5 & 2176219 & 8.68 & 71.07 \\
Korea, Rep. & 1609206 & 551193 & 0.15 & 0.00 & 2077730 & 534817 & 29.19 & 0.00 \\
Lao PDR & 413379.1 & 24646 & 0.27 & 98.37 & 366663.3 & 18916 & 22.17 & 62.53 \\
Malaysia & 1458944 & 1639138 & 5.69 & 86.56 & 1481202 & 2357603 & 78.05 & 86.03 \\
Myanmar & 426860.2 & 117435 & 13.17 & 45.91 & 514666.9 & 98008 & 61.26 & 41.55 \\
Philippines & 3631405 & 374458 & 8.39 & 14.43 & 4275612 & 435423 & 12.42 & 14.43 \\
Singapore & 230006.8 & 1842953 & 41.21 & 0.02 & 297234.3 & 1966865 & 37.63 & 84.44 \\
Thailand & 758179.7 & 1050459 & 30.26 & 0.00 & 811122.8 & 1157263 & 36.97 & 73.84 \\
Viet Nam & 2225413 & 21105 & 7.80 & 0.00 & 2226401 & 69307 & 12.89 & 0.00 \\
\hline
\end{tabular}

^Source: Author's computation based on migration data from http://go.worldbank.org/JITC7NYTTO. Accessed 31 July, 2012.

Table 3 shows the ratio of outbound and inbound migration to EU 6 countries and US. Each county has computed average outbound and inbound intra East Asia migration ratio for 50 years. Comparing the average outbound and inbound intra East Asia migration ratio of each country to each country's outbound and inbound migration ratio to European Union 6 and United States, majority of the East Asian countries have higher incidence of labor movement outside East Asia. The asterisk $\left(^{*}\right)$ indicates outbound movement with nil inbound movement to a particular country. For instance, many Vietnamese moved to any European Union 6 countries than any resident of these countries to move in Vietnam.

Table 3. Ratio of Outbound and Inbound Migration to EU 6 countries and US

\begin{tabular}{|c|c|c|c|c|c|c|}
\hline EAST ASIA, EU 6 \& US & 1960 & 1970 & 1980 & 1990 & 2000 & 2010 \\
\hline \multicolumn{7}{|c|}{ Brunei Darussalam (1.2) } \\
\hline EU 6 & 0 & 0 & 0 & 0 & * & 1.4 \\
\hline United States & 0 & 0 & * & * & 0 & 3.7 \\
\hline \multicolumn{7}{|c|}{ Cambodia (3.5) } \\
\hline EU 6 & 6 & 2 & - & - & 56 & 42.8 \\
\hline United States & 1 & 1 & - & - & 141 & 159.4 \\
\hline \multicolumn{7}{|c|}{ China (31.0) } \\
\hline EU 6 & * & * & * & * & 214 & - \\
\hline United States & 11.7 & 73.7 & 320.0 & 191.3 & 127 & - \\
\hline \multicolumn{7}{|c|}{ Indonesia (348.0) } \\
\hline EU 6 & * & * & * & * & * & * \\
\hline United States & 0.7 & 0.5 & 16.5 & 17.7 & 40 & * \\
\hline \multicolumn{7}{|c|}{ Japan (0.8) } \\
\hline EU 6 & 9 & * & * & 5.4 & 6.1 & 35.9 \\
\hline United States & 9.6 & 7.6 & 15.3 & 11.0 & 10.0 & 10.0 \\
\hline \multicolumn{7}{|c|}{ Korea (34.8) } \\
\hline EU 6 & * & * & 18 & 36 & 18.5 & * \\
\hline United States & 2.2 & 29.5 & 78.3 & 173.5 & 74.8 & * \\
\hline \multicolumn{7}{|c|}{ Lao (115.6) } \\
\hline EU 6 & * & * & * & * & * & * \\
\hline United States & * & * & * & * & * & * \\
\hline \multicolumn{7}{|c|}{ Malaysia (10.4) } \\
\hline EU 6 & * & * & * & 2 & 3.2 & * \\
\hline United States & * & * & 12 & 11.7 & 17.7 & * \\
\hline
\end{tabular}




\begin{tabular}{|c|c|c|c|c|c|c|}
\hline EAST ASIA, EU 6 \& US & 1960 & 1970 & 1980 & 1990 & 2000 & 2010 \\
\hline \multicolumn{7}{|c|}{ Myanmar (129.9) } \\
\hline EU 6 & * & 0 & 0 & 0 & $*$ & 0.0 \\
\hline United States & 0.3 & 0.3 & 6.5 & 22.0 & 36.0 & 2.7 \\
\hline \multicolumn{7}{|c|}{ Philippines (141.8) } \\
\hline EU 6 & * & 10 & * & 85 & 41.3 & 38.9 \\
\hline United States & 112 & 12.4 & 49.2 & 53.0 & 41.8 & 38.4 \\
\hline \multicolumn{7}{|c|}{ Singapore (1.2) } \\
\hline EU 6 & * & * & * & 1.5 & 8 & * \\
\hline United States & 0 & 0 & 7 & 7.5 & 3.4 & 3.8 \\
\hline \multicolumn{7}{|c|}{ Thailand (6.2) } \\
\hline EU 6 & * & * & 2 & 10.5 & 4.3 & 15.5 \\
\hline United States & 2 & 1 & 22.3 & 42.3 & 26.7 & 17.3 \\
\hline \multicolumn{7}{|c|}{ Vietnam (35.1) } \\
\hline EU 6 & * & * & * & * & * & - \\
\hline United States & * & * & * & * & 1028 & - \\
\hline
\end{tabular}

Note: (.) Figures inside the parenthesis indicate the average outbound and inbound ratio within ASEAN +3 .

* Indicates no inbound incidence.

EU 6 countries includes Belgium, France, Germany, Italy, Luxembourg and the Netherlands.

^Source: Author's computation based on migration data from http://go.worldbank.org/JITC7NYTTO. Accessed 31 July, 2012.

\subsection{Capital Mobility}

Flow of foreign direct investment (FDI) into East Asia speaks the competitiveness of the region with the rest of the world. In 1980, the ratio of FDI to GDP of several East Asian countries is higher than countries like Germany and United States. However, the 1997 Asian crisis unevenly impacted countries in East Asia. As shown in Table 4, countries heavily affected in terms of a reduction in the share of foreign direct investment (FDI) to gross fixed capital formation (GFCF) were Cambodia (but easily got its momentum in 1998, in which its share of FDI to GFCF was as high as its share of FDI to GFCF in year 1996), Indonesia (share of FDI to GFCF in year 1997 was the same in the previous year but went negative in year 1998, investment only picked in 2004), and Lao PDR (reduction in the share of FDI to GFCF was as low its 1994 figure). There were also countries that despite the Asian crisis, continuously increase the share of FDI to GFCF like Myanmar, Singapore and Vietnam.

Table 4. Average Foreign Direct Investment (FDI) inflows as a percentage of Gross Fixed Capital Formation (GFCF)

\begin{tabular}{|c|c|c|c|c|}
\hline Countries & $1990-1996$ & $1997-1998$ & $1999-2006$ & $\mathbf{2 0 0 7 - 2 0 1 0}$ \\
\hline Brunei Darussalam & 9.73 & 39.9 & 91.53 & 21.85 \\
China & 10.37 & 13.8 & 8.91 & 5.07 \\
Cambodia & 23.56 & 49.5 & 24.30 & 41.37 \\
Indonesia & 5.56 & 3.4 & -1.07 & 5.44 \\
Japan & 0.09 & 0.3 & 0.56 & 1.35 \\
Korea, Republic of & 0.68 & 3.1 & 3.65 & 2.36 \\
Lao PDR & 28.58 & 38.8 & 9.36 & 17.44 \\
Malaysia & 18.59 & 13.9 & 14.31 & 15.10 \\
Myanmar & 26.55 & 80.8 & 23.76 & 26.45 \\
Philippines & 7.89 & 9.5 & 9.34 & 8.55 \\
Singapore & 31.50 & 30.1 & 62.06 & 52.50 \\
Thailand & 4.22 & 18.8 & 16.07 & 10.93 \\
Viet Nam & 32.70 & 29.6 & 13.10 & 25.37 \\
\hline East Asia (average) & 15.39 & 25.5 & 15.64 & 17.98 \\
\hline United States & 3.97 & 8.5 & 8.12 & 9.52 \\
Germany & 0.92 & 4.0 & 13.47 & 6.89 \\
France & 6.71 & 10.5 & 15.79 & 10.03 \\
Netherlands & 12.07 & 27.2 & 36.23 & 22.39 \\
\hline
\end{tabular}

^Source: Author's computation based on FDI data from http://unctad.org/Sections/dite_dir/docs/WIR11_web tab 5.xls. 
Likewise, countries with notable investment agreement with United States and Europe had a remarkable reduction in their share of foreign direct investment to gross fixed capital formation. For example countries Brunei Darussalam, China, Korea and Singapore receive investments from countries European Union and United States. The crises from these countries lower the funnel of investment into some East Asian countries.

Furthermore, share of foreign direct investment to gross fixed capital formation for some reasons has unsteady trend. Despite of that, the average East Asian share of foreign direct investment to gross fixed capital formation is relatively higher compared to developed counties like United States, Germany and France.

Table 5. FDI Flows to ASEAN

Cross-Tabulation: FDI East Asian Source Countries and ASEAN Host Countries Cumulative 1995-2005

\begin{tabular}{|c|c|c|c|c|c|c|c|c|c|c|c|}
\hline \multirow{2}{*}{ Source Country } & \multicolumn{10}{|c|}{ Host Country } & \multirow{2}{*}{$\begin{array}{l}\text { Total Cumulative 1995- } \\
\qquad 2005\end{array}$} \\
\hline & $\mathrm{BN}$ & $\mathrm{KH}$ & ID & LA & MY & MM & $\mathrm{PH}$ & SG & TH & VN & \\
\hline Japan & 379 & 5 & 386 & 19 & 6087 & 119 & 3164 & 12202 & 9404 & 2619 & 34384 \\
\hline China & 3 & 214 & 557 & 37 & 121 & 156 & 304 & 360 & 57 & 237 & 2046 \\
\hline Republic of Korea & 39 & 120 & 836 & 110 & 125 & 56 & 242 & 655 & 306 & 1687 & 4176 \\
\hline Brunei D. & - & - & -27 & 0 & 299 & - & 0 & 195 & 4 & 2 & 473 \\
\hline Cambodia & - & - & - & 0 & 3 & - & - & 6 & 13 & 1 & 22 \\
\hline Indonesia & 57 & 1 & 0 & - & 293 & 39 & 39 & 3388 & 44 & 61 & 3922 \\
\hline Lao PDR & - & - & - & - & 0 & - & 0 & 1 & -1 & 12 & 12 \\
\hline Malaysia & 232 & 55 & 976 & 97 & - & 57 & 88 & 4046 & 227 & 578 & 6356 \\
\hline Philippines & 5 & 2 & 13 & - & 97 & 4 & 0 & 105 & 223 & 49 & 498 \\
\hline Singapore & 1117 & 55 & 954 & 11 & 7623 & 750 & 1167 & - & 5999 & 1910 & 19586 \\
\hline Thailand & 8 & 87 & 144 & 161 & 209 & 196 & 23 & 406 & - & 492 & 1725 \\
\hline Viet Nam & 0 & 27 & - & 6 & 38 & - & 0 & 24 & 6 & - & 101 \\
\hline FDI in Cambodia $(1995-2000)$ & & 1236 & & & & & & & & & 1236 \\
\hline Philippines' data on Reinvested Earnings (1999- & & & & & & & 392 & & & & 392 \\
\hline Singapore's data on Inter-Company Loans (2005) & & & & & & & & 21 & & & 21 \\
\hline Total & 1841 & 1802 & 3840 & 442 & 14894 & 1377 & 5418 & 21409 & 16282 & 7646 & 74951 \\
\hline
\end{tabular}

^Source: Author's modification based from the Statistics of Foreign Direct Investment in ASEAN, ASEAN SecretariatEight Edition, 2006.

Data compiled from the respective ASEAN Central Banks and Central Statistics Offices.

Unless otherwise indicated, the figures include equity and inter-company loans.

Figures for Brunei Darussalam, Cambodia, Malaysia (for the whole data series) and figures for Myanmar and Viet Nam (for 2003-20 reinvested earnings.

Cambodia submitted FDI data by source countries starting 2001.

Figures for Singapore include reinvested earnings for the whole data series, but exclude inter-company loans for 1995-1996. Figures for 2004 are preliminary.

Intra East Asian flow of foreign direct investment for 10 years is reflected in Table 5. Amongst the East Asian countries, Japan extends heavily on direct investments to all Association of South East Asian Nations (ASEAN) members, followed by Singapore and Republic of Korean. Likewise, major recipients of foreign direct investment from East Asian neighbors are Singapore Thailand and Malaysia, in descending order of foreign direct investment flows. Note that these countries invest heavily on each other. Conversely, Japan is the major investor in Singapore. Both are industrialized countries in the region. Lastly, Lao PDR spends less on FDI to all ASEAN counties and receives less FDIs from all East Asian neighbors.

\subsection{Trade Openness}

The trading agreement within Association of South East Asian Nations (ASEAN) has increased the volume of trading of each ASEAN member, although the magnitude of the flourishing trading may be unevenly distributed to each member. There are countries that lag behind their neighbors while others steadily moving but at a calculated pace, but comparatively they are better off after joining the trade group.

The intra-ASEAN trading is comparatively low than other trade groups in which ASEAN trades. Table 6 shows that 
for a span of four periods, the increment of the share of intra regional trading of ASEAN's total trade to the rest of the world moves at a steady pace of less than four percent. From 2002 to 2007, share of intra ASEAN group to ASEAN total trade to the rest of the world increased only by one percent. For instance, in year 2007, intra-ASEAN trading account for about 25 percent of ASEAN's total trade, this is one percent higher than in 2002.

Although compared with ASEAN trading with EU 25 and United States, the change in the share of intra trading of EU25 and US to ASEAN total trade is almost nil. It even reduced in year 2002 to 2007. Apparently, nothing unusual about the data because practically it is too costly to trade across boundaries, it is relatively cheaper to trade at shorter proximity than farther. This explains the large contribution of intra East Asia to the ASEAN total trade. Geographically, the trading partners are nearer.

Table 6. Share of Intra-Trading Group to the ASEAN Total Trade

\begin{tabular}{|l|c|c|c|c|}
\hline Trade Groupings & $\mathbf{1 9 9 2}$ & $\mathbf{1 9 9 7}$ & $\mathbf{2 0 0 2}$ & $\mathbf{2 0 0 7}$ \\
\hline Intra-ASEAN & 18 & 21 & 24 & 25 \\
Intra-East Asia & 45 & 45 & 48 & 51 \\
EU 25 with ASEAN & 16 & 15 & 13 & 12 \\
USA with ASEAN & 17 & 17 & 16 & 11 \\
\hline
\end{tabular}

^Source: United Nations Conference of Trade and Development

The trading partners of each ASEAN member are shown in Table 7. As reflected in the table, intensive intra-regional trading is evident, although asymmetric. For example, Cambodia imports intensively in East Asia but exports heavily in United States. Lao PDR, on the other hand, buys in East Asia but sells heavily in European Union.

Table 7. ASEAN Trade by Member States and Major Trade Partners in 2007

\begin{tabular}{|c|c|c|c|c|c|c|}
\hline \multirow{2}{*}{ Countries } & \multicolumn{2}{|c|}{ East Asia } & \multicolumn{2}{c|}{ European Union } & \multicolumn{2}{c|}{ United States } \\
\cline { 2 - 7 } & Imports & Exports & Imports & Exports & Imports & Exports \\
\hline Brunei D. & 22.31 & 47.99 & 10.76 & 0.24 & 9.03 & 6.73 \\
Cambodia & 25.42 & 2.24 & 4.91 & 21.21 & 1.12 & 46.88 \\
Indonesia & 24.55 & 35.84 & 10.29 & 11.64 & 6.44 & 10.21 \\
Lao PDR & 28.12 & 13.64 & 4.72 & 35.19 & 0.92 & 1.60 \\
Malaysia & 30.78 & 21.70 & 11.85 & 12.80 & 10.84 & 15.64 \\
Myanmar & 52.73 & 18.90 & 3.76 & 12.82 & 0.28 & 0.00 \\
Philippines & 25.62 & 29.41 & 9.54 & 17.01 & 13.99 & 17.05 \\
Singapore & 25.18 & 18.01 & 12.28 & 10.80 & 12.43 & 8.91 \\
Thailand & 36.57 & 23.44 & 8.34 & 13.89 & 6.69 & 12.62 \\
Viet Nam & 35.65 & 23.42 & 6.97 & 17.82 & 2.20 & 19.71 \\
\hline
\end{tabular}

*Data from Brunei D., Lao PDR, Myanmar and Viet Nam as of 2006

Data from Cambodia as of 2004.

^Source: All data on trade is generated with the World Integrated Data Solution. (http://wits.worldbank.org/wits/)

\subsection{Product Diversification}

Japan has been in a limelight as a good performing country in Asia. Until, its spotlight was shared by countries with exceptional growth rates, famously called "Asian tigers" - Hong Kong, Taiwan, Singapore and South Korea which emerged in early 1960s. By the end of the $20^{\text {th }}$ century, these countries and including some developing countries in East Asia, accounted for more than 80 percent of the total regional trade. However, the reawakening of China's economy to the rest of the world has exceptional effect even outside of the region.

The share of manufacturing to total exports has seen to be rising in Asian tradable goods. However, as shown in table 8, North American Free Trade Agreement (NAFTA) and EU 15 have more diversified exports than the rest. Machinery and transport equipment is the major exports for all countries and trade groups. For Japan, the second major export is road vehicles followed by information and communication technology (ICT) products. Information and communication technology (ICT) products are the second major export of China, Taiwan (TK), Korea and ASEAN countries. It is also the second major exports of NAFTA and EU 15 but the volume of trade is relatively lower than those countries mentioned earlier. This product has become an important source of revenue by most countries in South East Asia.

Aside from ICT products, semiconductors and semiconductor devices are another income generating exports of 
Taiwan, Korea and ASEAN countries. On the other hand, commodities like chemicals, resource-based products and professional and scientific equipment are NAFTA and EU 15 comparative advantage products. In terms of exports value, NAFTA and EU have relatively higher exports than Asian countries.

Table 8. Composition of manufacturing exports, 2006-07 (per cent)

\begin{tabular}{|l|c|c|c|c|c|c|}
\hline Commodity group & Japan & China & TW+K & ASEAN & NAFTA & EU 15 \\
\hline Chemical (SITC 5) & 0.1 & 0.1 & 0.1 & 0.0 & 0.2 & 0.2 \\
\hline Resource - based products (SITC 6-SITC 68) & 1.8 & 1.0 & 1.0 & 0.7 & 2.1 & 2.8 \\
\hline Machinery and transport equipment (SITC 7) & 87.5 & 91.6 & 84.0 & 94.7 & 86.0 & 87.9 \\
\hline Power generating machines (SITC 71) & 3.8 & 1.1 & 1.1 & 1.2 & 9.0 & 6.6 \\
\hline Specialized industrial machines (SITC 72) & 3.5 & 1.8 & 1.1 & 2.3 & 2.6 & 3.5 \\
\hline Metal-working machines (SITC 73) & 0.6 & 0.2 & 0.3 & 0.1 & 0.4 & 0.7 \\
\hline General industry machinery (SITC 74) & 1.7 & 1.4 & 0.9 & 1.2 & 2.4 & 3.5 \\
\hline ICT products & 33.2 & 69.2 & 59.7 & 78.3 & 27.6 & 22.9 \\
\hline Office/automatic data-processing machines (SITC 75) & 8.2 & 29.0 & 8.7 & 27.0 & 7.2 & 7.6 \\
\hline Telecommunication and sound-recording equipment (SITC 76) & 9.0 & 28.3 & 16.1 & 14.9 & 9.6 & 7.9 \\
\hline Semiconductors and semiconductor devices (SITC 772+776) & 16.0 & 11.8 & 34.9 & 36.4 & 10.8 & 7.5 \\
\hline Electrical goods (SITC 77-772-776) & 8.1 & 14.2 & 6.1 & 6.4 & 8.2 & 8.5 \\
\hline Road vehicles (SITC 78) & 35.0 & 3.2 & 12.6 & 4.4 & 26.5 & 36.4 \\
\hline Other transport equipment (SITC 79) & 1.6 & 0.7 & 2.3 & 0.9 & 9.3 & 5.7 \\
\hline Miscellaneous manufacturing (SITC 8) & 10.6 & 7.3 & 14.9 & 4.6 & 11.8 & 9.1 \\
\hline Professional and scientific equipment (SITC 87) & 5.8 & 4.0 & 11.0 & 2.6 & 8.2 & 5.9 \\
\hline Photographic apparatus (SITC 88) & 3.6 & 2.4 & 1.2 & 1.3 & 1.3 & 1.8 \\
\hline Total manufacturing exports & 100.0 & 100.0 & 100.0 & 100.0 & 100.0 & 100.0 \\
\hline US \$billion & 428.0 & 656.0 & 359.0 & 348.0 & 739.0 & 1366.0 \\
\hline
\end{tabular}

${ }^{\star}$ ASEAN excludes Brunei Darussalam, Cambodia, Lao PDR and Myanmar.

Source: Prema-Chandra A. and A. Kohpaiboon, 2011. Intra-Regional Trade in East Asia: The Decoupling Fallacy, Crisis and Policy Challenges, ADBI Working Paper

Trade pattern relative to higher tradable manufactured commodities and fewer agricultural commodities means increasing the potential of higher revenue from exports. As presented in Table 9, share of parts and components in manufacturing trade has tremendously increased for both exports and imports. Amongst ASEAN countries, Philippines has the highest share of parts and components in manufacturing trade for both exports and imports. Malaysia, on the other hand, has slight increase in imports from period 1992-93 to 2006-07, recall that this country was heavily affected by Asian crisis. Singapore has also considerable share of part and components in manufacturing trade for both exports and imports. Despite a low share of parts and components in manufacturing trade of some countries in East Asia, still comparatively higher than EU 15 and NAFTA's share of part and components in manufacturing trade.

Table 9. Share of parts and components in manufacturing trade, 1992-03 and 2006-07 (per cent)

\begin{tabular}{|c|c|c|c|c|}
\hline \multirow{2}{*}{ Countries/ Trade Group } & \multicolumn{2}{|c|}{ Exports } & \multicolumn{2}{c|}{ Imports } \\
\cline { 2 - 5 } & $\mathbf{1 9 9 2 - 9 3}$ & $\mathbf{2 0 0 6 - 0 7}$ & $\mathbf{1 9 9 2 - 9 3}$ & $\mathbf{2 0 0 6 - 0 7}$ \\
\hline ASEAN & 22.7 & 44.2 & 36 & 47.9 \\
Indonesia & 3.8 & 21.5 & 27 & 21.8 \\
Malaysia & 27.7 & 53.6 & 40.5 & 50 \\
Philippines & 32.9 & 71.7 & 32.6 & 61.3 \\
Singapore & 29 & 49.3 & 39.9 & 60.4 \\
Thailand & 14.1 & 29.9 & 30.6 & 36.1 \\
Viet Nam & n.a & 11 & n.a & 19.1 \\
Japan & 23.9 & 34.4 & 19.3 & 29.9 \\
China & 7.4 & 25.6 & 20.4 & 44 \\
Republic of Korea & 18.1 & 47.3 & 30.1 & 31.9 \\
EU 15 & 18.3 & 22.4 & 21.2 & 23.2 \\
NAFTA & 28.4 & 31.2 & 37.4 & 28.8 \\
\hline
\end{tabular}

Source: Prema-Chandra A. and A. Kohpaiboon, 2011.Intra-Regional Trade in East Asia: The Decoupling Fallacy, Crisis and Policy Challenges, ADBI Working Paper 


\section{Conclusion and Recommendations}

The bases of currency union employed in this study are: factor mobility, trade openness and product diversification. Results indicate that within East Asian countries, intra labor mobility is immobile. Labor would rather move to European Union 6 countries and United States than stay within the region. Intra capital mobility, on the other hand, is slightly mobile. The average East Asian share of foreign direct investment to gross fixed capital formation is relatively higher compared to developed counties like United States, Germany and France. In terms of trade openness, the volume of trade is relatively higher within the region than the volume of trade in European Union 6 countries and United States. However, it is less symmetric. This means, some countries exports within the region but imports outside the region. Furthermore, there has been increasing diversification of trade within the region. There is even a rise of the share of parts and components in manufacturing. Hence, base on the given results, East Asia is not yet ready to form a currency union.

Having described the factor mobility (or immobility), trade intensity and composition of tradable goods of East Asia countries, benefits for establishing a currency union may not be as optimal as what most Asian government imagined. It might even be detrimental to some countries growth. Hence, it might cause more losses than gains.

Hence, this paper recommends the following: first, political integration is a precursor to unified currency to work. As mentioned earlier, symmetry of shock comes from symmetry of policies across countries. Second, this paper is just one of the many attempts to examine the feasibility to establish currency union, and most often than not, the conclusion is similar - the region is not yet ready. Recently, the region adopts zero tariffs to 99.11 percent tradable goods. This is an attempt to foster intra trading. Hence, additional research should be conducted to see the impact of this new trade agreement. Lastly, prior to the formation of Europe Monetary Union many cynics were waiting for the downfall of the European currency union. There are literature justifying its non optimal currency union, and yet it still standing amidst controversies. Therefore, as long as the losses are greater than the benefits, and as long as all countries are better off than its initial state (without currency union) then the losses are justifiable.

\section{References}

Albertin, Giorgia, 2008. "Trade Effects of Currency Unions: Do Economic Dissimilarities Matter" International Monetary Fund Working Paper. WP/08/249 < www.imf.org/external/pubs/tt/wp/2008/wp08249.pdf>

Amjadi, Azita \& Winters, Alan, 1997. "Transport Costs and "Natural" Integration in Mercosur." The World Bank, Policy Research Working Paper 1742

Alesina, Alberto \& Barro, Robert 2002. "Currency Unions," Quarterly Journal of Economics, pp. 409-36.

Allington, Nigel FB., Kattuman, Paul A. \& Waldmann, Florian A. 2005. "One Market, One Money, One Price?"MPRA Paper No. 835, posted 07. November 2007. < http://mpra.ub.uni-muenchen.de/835/>

Arısoy, Ibrahim \& Uçak, Harun, 2012 "Saving, Investment and Capital Mobility in G-7 Countries: Time Varying Parameters Approach" International Research Journal of Finance and Economics, Issue 58 (2010) <http://www.eurojournals.com/finance.htm>

Baldwin, John, Cavas, Richard \& Gu, Wulong, 2005 "Responses to Trade Liberalization: Changes in Product Diversification in Foreignand Domestic-Controlled Plants", Economic Analysis (EA) Research Paper Series Statistics Canada - Catalogue No. 11F0027 No. 031

Barro, R. J. and X. Sala-i-Martin. 1991. "Convergence across States and Regions." Brookings Papers on Economic Activity 1: 107-158

Barro, Robert J., Mankiw, N. Gregory, Sala-I-Martin, Xavier, 1995. "Capital Mobility in Neoclassical Models of Growth," The American Economic Review, Vol. 85, No. 1. pp. 103-115.

Bayoumi, Tamim, 1994. "A Formal Model of Optimum Currency Areas" International Monetary Fund Working Paper. WP/94/42

Bentivogli, Chiara \& Pagano, Patrizio, 1999, "Regional Disparities and Labour Mobility: the Euro-11 versus the USA", LABOUR 13 (3) 737-760.

Beetsma, R., Debrun, X \& Klaassen, F., 2001. "Is fiscal policy coordination in EMU desirable?" Swedish Economics Policy Review 8 pp. 57-98

Bonin, Holger et al., 2008 Geographic Mobility in the European Union. Optimising its Economic and Social Benefits, Report for the European Commission, Bonn

Buch, Claudia M, 1999. "Capital Mobility and EU Enlargement" Kiel Working Paper No. 908

Busetti, F., Forni, L., Harvey, A., 2004. "Inflation Convergence and Divergence Within the European Monetary Union". International Journal of Central Banking. Vol. 3 No. 2

Cooper, Russell. 2012. "Exit from a Monetary Union Through Euroization: Discipline without Chaos". NBER Working Paper 17908 $<$ http://www.nber.org/papers/w17908>

Costa Neto, Nelson Camanho da \& Romeu, Rafael, 2011. "Did Export Diversification Soften the Impact of the Global Financial Crisis?" International Monetary Fund Working Paper. WP/11/99 < http://www.imf.org/external/pubs/ft/wp/2011/wp1199.pdf>

De Pace, Pierangelo, 2011. "Currency Union, Free-Trade Areas, and Business Cycle Synchronization" Available at SSRN: http://ssrn.com/abstract=1281763 or http://dx.doi.org/10.2139/ssrn.1281763 
De Grauwe, Paul, 2011. "The Governance of a Fragile Eurozone" CEPS Working Documents No. 346

Eichengreen, Barry, 1993. "Labor markets and European monetary unification." In Policy issues in the operation of currency unions, edited by P. Masson and M. Taylor, 130-162. Cambridge: Cambridge University Press.

Emerson, M. et al., 2004. "One Market, OneMoney: An Evaluation of the Potential Benefits and Costs of Forming an Economic and Monetary Union". Oxford; New York; Toronto and Melbourne Oxford University Press,, p. 354.

Frankel, Jeffrey A. \& Rose, Andrew K., 1998 "The Endogeneity of the Optimum Currency Area Criteria" Economic Journal.

Global Migration Database < http: data.worldbank.org/data-catalog/global-bilateral-migration-database

Isgut, Alberto E, 2002. "Common Currencies and Market Integration across Cities: How Strong is the Link?" Mimeo, Department of Economics, Wesleyan College, Middletown, Connecticut.

Kenen, Peter, 1969, "The Theory of Optimum Currency Areas: An Eclectic View" in Mundell and Swoboda (eds.) Monetary Problems in the International Economy, University of Chicago Press, Chicago United States.

Kun, János,2003. "Seigniorage in Selected Acceding Countries: Current Situation and Future Prospects on the Road towards Monetary Integration" Transelektro Group Budapest < www.oenb.at/en/img/kun_ftr_203_tcm16-10374.pdfs

Kurokawa, Y., Pang, J.; Tang, Y., 2011 "Exchange Rate Regimes, Trade, and the Wage Comovements" <http://www.bowdoin.edu/ ytang/KPT1_08_11_11.pdfs

Lee, Jong-Wha and Shin, Kwanho. September 2004. "Exchange Rate Regimes and Economic Linkages" Available at SSRN: http://ssrn.com/abstract=596026 or http://dx.doi.org/10.2139/ssrn.596026

McKinnon, R., 1963, "Optimum Currency Area", American Economic Review, September, pp. 717-725.

Mundell, Robert, 1961, "A Theory of Optimum Currency Areas", American Economic Review, Sept., 657-665.

Obstfeld, Maurice,2001. International Macroeconomics: Beyond the Mundell-Fleming Model. International Monetary Fund Staff Papers 47: 1-39

Prema-Chandra A. \& Kohpaiboon, A. 2011. "Intra-Regional Trade in East Asia: The Decoupling Fallacy, Crisis and Policy Challenges", ADBI Working Paper

Puente, Sergio. 2003. "Inflation Effects of a Monetary Union". <www.eco.uc3m.es/temp/jobmarket/Money.pdfs

Rose, Andrew, 2000. "One Money One Market: Estimating the Effect of Common Currencies on Trade." Economic Policy, pp: 7-46.

Sahin, Hasan, 2006. "MENA countries as optimal currency areas: Reality or Dream." Journal of Policy Modeling 28 no. 5: 511-521.

Sinn, Hans-Werner and Feist, Holger. 1997. "Eurowinners and Eurolosers: The Distribution of Seigniorage Wealth in EMU". CES Working Paper at Univ. of Munich \#134. Available at SSRN: <http://ssrn.com/abstract=37586>

Tenreyro, Silvana Lisicky, Milan Koren, Miklos Caselli, Francesco, 2011. "Diversification through Trade" <http://personal.Ise.ac.uk/ tenreyro/volatilitytrade.pdf>

Tenreyro, Silvana, 2001. "On The Causes and Consequences of Currency Unions" Harvard University Cambridge

United Nations Conference on Trade and Development. <http://unctad.org/en/Pages/Statistics.aspx>

World Integrated Trade Solution <http://wits.worldbank.org/witsweb/,20.05.2009> 